\title{
KARAKTERISTIK PERJANJIAN KEAGENAN DALAM KAJIAN HUKUM PERDATA
}

\author{
Rosida Diani ${ }^{1}$ \\ Mahendra Kusuma ${ }^{2}$ \\ rosida@unitaspalembang.ac.id \\ 1,2Fakultas Hukum Universitas Tamansiswa Palembang, Indonesia
}

\begin{abstract}
Abstrak: Perjanjian keagenan merupakan perjanjian yang muncul dan berkembang dimasyarakat namun tidak diatur secara khusus di dalam KUHPerdata, sehingga dapat dikategorikan sebagai perjanjian innominaat. Pengaturan khusus perjanjian keagenan ini hingga saat ini belum ada, sehingga apabila terjadi sengketa maka merujuk pada perjanjian keagenan yang telah dibuat oleh para pihak. Apabila ada hal-hal yang tidak diatur secara khusus dalam perjanjian itu maka akan diberlakukan aturan-aturan umum mengenai pemberian kuasa sebagaimana tercantum di dalam KUHPerdata. Perjanjian keagenan ini mempunyai karakteristik yang hampir sama dengan perjanjian komis antara komisionter dan komiten. Sehingga aturan-aturan di dalam KUHD mengenai perjanjian komisi juga dapat diterapkan dalam perjanjian keagenan dalamhal tidak diatur secara khusus dalam perjanjian keagenan para pihak.
\end{abstract}

Kata Kunci: Perjanjian Keagenan, Pemberian Kuasa

Abstract: Agency agreement is an agreement that appears and develops in the community but is not specifically regulated in the Civil Code, so it can be categorized as an innominate agreement. Until now, there is no specific arrangement for this agency agreement, so if there is a dispute, it will refer to the agency agreement that has been made by the parties. If there are things that are not specifically regulated in the agreement, general rules regarding the granting of power as stated in the Civil Code will apply. This agency agreement has almost the same characteristics as the commission agreement between the commissioner and the committee. So that the rules in the KUHD regarding commission agreements can also be applied in agency agreements if they are not specifically regulated in the agency agreement of the parties.

Keywords: Agency Agreement, Authorization

\section{LATAR BELAKANG}

Abad ke-21 adalah abad globalisasi yang ditandai dengan adanya keterbukaan dan kebebasan dalam berbagai bidang kehidupan. Menurut Solly Lubis, kata globalisasi berasal dari "globe" yaitu bumi tempat hunian manusia. ${ }^{1}$ Definisi globalisasi adalah peruntuhan batas-batas dan jarak antara bangsa-bangsa, antara negara dan negara, antara budaya yang satu dengan yang lain. Dalam arus globalisasi ini, manusia akan berhubungan secara dekat dalam apa yang disebut dalam budaya lokal, pasar global, famili global dan sebagainya. ${ }^{2}$

\footnotetext{
${ }^{1}$ Solly Lubi, Kita dan Pengembangan Global tahun 2002 , makalah pada seminar nasional
} Hakim Peradilan Agama, PTA Sumatera Utara Medan, Hotel Darma Deli Medan, 2002, hlm.3

${ }^{2}$ Abdul Manan, Aspek-Aspek Pengubah Hukum, Kencana, Jakarta, 2006, hlm.58 
Globalisasi memberikan banyak perubahan terutama dalam bidang ekonomi. Salah satu bentuknya adalah banyak lahir pranata-pranata baru dalam praktik namun secara yuridis belum ada pengaturan khususnya. Contoh dari hal ini adalah agen. Agen merupakan pedagang perantara. Tugas utama pedagang perantara adalah menghubungkan produsen dengan konsumen. ${ }^{3}$

Demi alasan efisiensi, maka produsen tidak menjual barang dan jasa langsung kepada konsumen, tetapi menjualnya melalui pedagang perantara atau middle man seperti agen, distributor, ataupun memberikan lisensi untuk memproduksi dan mendistribusikan barang dan jasa melalui sistem franchise. ${ }^{4}$

Dalam hubungan hukum antara produsen dengan agen, produsen berkedudukan sebagai prinsipal. Definisi agen adalah seseorang atau suatu perusahaan yang mewakili pihak lain (yang disebut dengan prinsipal) untuk melakukan bisnis (misalnya menjual produk) untuk dan atas nama prinsipal kepada pihak ketiga dalam suatu wilayah pemasaran tertentu, di mana sebagai imbalan atas jerih payahnya itu, agen akan mendapatkan komisi tertentu. ${ }^{5}$

Masalah hukum keagenan ini juga banyak bersentuhan dengan hukum bisnis Internasional, mengingat karena keterbatasannya produsen luar negeri, sering kali menunjuk agen pemasaran dari produk-produknya disuatu negara produk pemasaran. Bagi kebanyakan produsen, hal ini jauh lebih menguntungkan dan praktis ketimbang dia membuka cabangnya sendiri di negara wilayah pemasaran produknya itu. $^{6}$

Dalam hubungan hukum antara produsen dengan agen, agen bertugas memperluas pemasaran barang dan atau jasa yang diproduksi oleh perusahaan. Hubungan ini diikat dalam suatu perjanjian yang disebut sebagai perjanjian keagenan. Dalam perjanjian keagenan inilah dicantumkan apa hak dan kewajiban masing-masing.

Sebagai suatu pranta yang belum mempunyai satu aturan yang khusus, maka pengaturan mengenai keagenan ini merujuk dalam beberapa aturan yang berkaitan

\footnotetext{
${ }^{3}$ Sentosa sembiring, Hukum dagang, Citra Aditya Bakti, Bandung, 2008, hlm.117

${ }^{4}$ Suharnoko, Hukum Perjanjian ; Teori dan Analisa Kasus, Kencana, Jakarta, 2008, hlm. 37

5 Munir Fuady, Pengantar Hukum Bisnis ; Menata Bisnis Modern di Era Global, Citra Aditya Bakti, Jakarta, 2002, hlm.244

${ }^{6}$ Ibid, hlm. 244
} 
dengan agen. Aturan-aturan itu antara lain, UU No.6 tahun 1968 tentang penanaman modal, PP No.36 tahun 1977 tentang pengakhiran kegiatan usaha asing dalam bidang perdagangan, tunduk juga dalam aturan KUHPerdata, KUHD. Oleh karena belum adanya peraturan yang khusus tersebut, maka apabila terjadi suatu sengketa maka karakteristik perjanjian keagenan itu harus dianalisis berdasarkan aturan yang ada yang dapat diterapkan dalam perjanjian keagenan. Berdasarkan hal tersebutlah maka di dalam penelitian ini akan diuraikan mengenai karakteristik perjanjian keagenan dalam kajian hukum perdata.

\section{PEMBAHASAN DAN ANALISIS}

Sebelum membicarakan keagenan, terlebih dahulu akan diuraikan mengenai perantara dalam proses distribusi barang dari produsen ke konsumen. Yang dimaksud dengan perantara adalah orang atau perusahaan yang menghubungkan aliran barang dari produsen ke konsumen akhir dan konsumen industrial. Dalam hal ini produsen dan konsumen dihubungkan dalam kegiatan pembelian dan penjualan kembali barang yang dihasilkan produsen kepada konsumen.

Perantara dibutuhkan terutama karena adanya beberapa kesenjangan di antara produsen dan konsumen. Kesenjangan tersebut adalah: ${ }^{7}$

(1) Geographical gap, yaitu gap yang disebabkan oleh tempat pemusatan produksi dan lokasi konsumen yang tersebar dimana-mana

(2) Time gap, yaitu kesenjangan yang terjadi karena adanya kenyataan bahwa pembelian atau konsumsi dilakukan hanya pada waktu-waktu tertentu sementara produksi (agar efektif) berlangsung terus-menerus sepanjang waktu.

(3) Quantity gap, yaitu gap yang terjadi karena jumlah barang yang dapat diproduksi secara ekonomis oleh produsen berbeda dengan kuantitas normal yang diinginkan atau dibutuhkannya, sementara di lain pihak produsen tidak tahu siapa dan dimana pembeli potensial berada.

Kesenjangan antara produsen dan konsumen tersebut dapat digambarkan sebagai berikut: ${ }^{8}$

${ }^{7}$ Philip Kotler dkk, Manajemen Pemasaran Perspektif Asia, Penerbit Andi, Yogyakarta, 


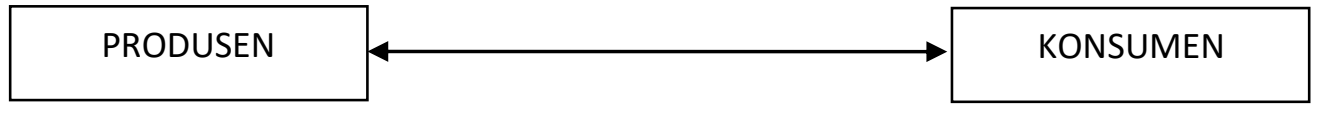

Geographical gap;time gap;quantity gap; assortment gap;communication and information gap

\section{Gambar 1 Kesenjangan antara produsen dan konsumen}

Secara umum perantara dibagi menjadi dua macam, yaitu:

(1) Merchant Middleman

Merchant middleman adalah perantara yang memiliki barang (dengan membeli dari produsen) untuk kemudian dijual kembali. Ada dua bentuk utama dari merchant middleman, yaitu:

(a) Wholesaler atau distributor

(b) Retailer

(2) Agent Middleman

Agent middleman adalah perantara yang hanya mencarikan pembeli, menegosiasikan dan melakukan transaksi atas nama produsen. Jadi ia tidak memiliki sendiri barang yang dinegosiasikan.

Perjanjian keagenan, berasal dari dua kata yaitu 'perjanjian' dan 'keagenan'. Kata perjanjian berarti suatu peristiwa di mana seorang berjanji kepada seorang lain atau di mana dua orang itu saling berjanji untuk melaksanakan sesuatu hal. ${ }^{9}$ Sedangkan keagenan berasal dari kata 'agen' yang mempunyai definisi sebagai orang yang mempunyai perusahaan untuk memberikan perantara membuat perjanjian tertentu (misalnya jual beli) diantara seorang yang mempunyai hubungan tetap dengan agen tersebut atau lebih dikenal dengan prinsipal dengan pihak ketiga atau juga membuat perjanjian atas nama perhitungan prinsipal itu. ${ }^{10}$

Menurut Abdul Kadir Muhammad, pengertian agen adalah orang diberi kuasa oleh orang disebut prinsipal, untuk mengadakan perjanjian dengan pihak ketiga atas

8 ibid

${ }^{9}$ Subekti, Hukum Perjanjian, Intermasa, Jakarta, 2002, hlm.1

10 KRMT. Titodiningrat, Ichtisar Hukum Perdata dan Hukum Dagang, pembangunan, jakarta, 1963, hlm.113 
nama prinsipalnya. Yang paling umum, tugas agen itu adalah mengadakan perjanjian antara prinsipalnya dan pihak ketiga. ${ }^{11}$ Sedangkan menurut Purwosutjipto, agen adalah orang yang melayani beberapa pengusaha sebagai perantara dengan pihak ketiga. Orang ini mempunyai hubungan tetap dengan pengusaha dan mewakilinya untuk mengadakan dan selanjutnya melaksanakan perjanjian dengan pihak ketiga. ${ }^{12}$

Hubungan agen dengan pengusaha bukan merupakan hubungan perburuhan, dan juga bukan hubungan pelayanan berkala. Bukan perburuhan karena hubungan antara agen perusahaan dengan perusahaan tidak bersifat subordinasi, bukan hubungan seperti majikan dan buruh, tetapi hubungan atnara pengusaha dengan pengusaha, jadi, sama tinggi sama rendah. Hubungan antara agen dengan pengusaha juga tidak bersifat pelayanan berkala sebab hubungan antara agen perusahaan dengan pengusaha bersifat tetap, sedangkan dalam pelayanan berkala hubungan itu bersifat tidak tetap. ${ }^{13}$

Oleh karena agen perusahaan juga mewakili pengusaha, maka disini juga ada hubungan pemberian kuasa. Perjanjian pemberian kuasa ini diatur di dalam Bab XVI Buku III KUHPer, mulai dengan pasal 1792 sampai dengan Pasal 1819. Perjanjian ini selalu mengandung unsur perwakilan (volmacht) bagi pemegang kuasa (pasal 1799 KUHPerdata). Dalam hal ini agen perusahaan sebagai pemegang kuasa mengadakan perjanjian dengan pihak ketiga atas nama pengusaha. Definisi perjanjian pemberian kuasa adalah perjanjian dengan seorang memberikan kuasa (wewenang) kepada seorang lain, yang menerimanya, untuk dan atas namanya menyelenggarakan suatu urusan (pasal 1792 KUHPerdata).

Kekuasaan atau wewenang yang diberikan untuk melakukan perbuatan hukum atas nama orang lain dalam bahasa Belanda disebut "volmacht", dalam bahasa inggris dinamakan "power of attorney". ${ }^{14}$ Menurut Wirjono Prodjodikoro, ${ }^{15}$ pengertian pemberian kuasa (lastgeving) adalah suatu persetujuan di mana seorang A memberikan kuasa kepada seorang B (kuasa mana diterima baik oleh B) untuk

\footnotetext{
${ }^{11}$ Abdulkadir Muhammad, Hukum Perjanjian, Penerbit Alumni, Bandung, 1986, hlm.278

12 H.M.N.Purwosutjipto, Pengertian Pokok Hukum Dagang Indonesai; Pengetahuan Dasar Hukum Dagang, Djambatan, Jakarta, 1999, hlm.47

13 ibid

${ }^{14}$ Subekti, Aneka Perjanjian, Citra Aditya Bakti, Bandung, 1995, hlm.142

${ }^{15}$ Wirjono Prodjodikoro, Hukum Perdata Tentang Persetujuan-Persetujuan Tertentu, Sumur, Bandung, 1981, hlm. 151
} 
melakukan hal sesuatu guna A dan atas nama A, 'hal sesuatu' (een zaak) lazimnya diartikan sebagai suatu perbuatan hukum (rechtshandeling).

Mengenai melakukan suatu urusan 'atas nama' pemberi kuasa, menimbulkan perdebatan, hal ini berkaitan dengan pemberian kuasa dan perwakilan. Menurut Van Brakel, bahwa yang dinamakan oleh KUHPer "pemberian kuasa" (lastgeving) itu adalah pemberian kuasa yang disertai dengan perwakilan, sedangkan pendapat kedua menganggap seolah-olah kata-kata "atas nama" itu tidak termuat dalam Pasal 1792 KUHPer, dan menganggap bahwa yang dimaksud oleh KUHPer dinamakan dan diatur selaku "lastgeving" itu ialah pemberian kuasa pada umumnya, jadi juga apabila tidak disertai perwakilan. Yang mengemukakan pendapat kedua ini yaitu Hofman dan Vollmar. ${ }^{16}$

Perwakilan berarti, bahwa dalam hubungan antara si penerima kuasa dan pihak ketiga yang diikat adalah si pemberi kuasa. Perwakilan ini tidak ada apabila si penerima kuasa bertindak terhadap pihak ketiga itu seolah-olah untuk kepentingan dan atas namanya sendiri, jadi seolah-olah tiada orang lain yang menyuruhnya demikian. Dengan kata lain, pemberian kuasa tanpa perwakilan hanya akan memberikan hubungan intern antara si pemberi kuasa dan si penerima kuasa, sedang perwakilan mengenai hubungan ekstern antara si pemberi kuasa dan pihak ketiga.

Terdapat hubungan yang erat antara pemberian kuasa dan perwakilan. Pemberian kuasa adalah salah satu sumber perwakilan, disamping sumber-sumber lainnya, yaitu undang-undang dan perjanjian-perjanjian lain, misalnya perjanjian perburuhan. Pemberian kuasa tidak selalu menimbulkan perwakilan, sedangkan sebaliknya perwakilan itu bisa timbul dari perjanjian-perjanjian lain juga. ${ }^{17}$ Dalam perjanjian keagenan, terdapat karakteristik perjanjian pemberian kuasa, dan di dalamnya juga terdapat perwakilan. Dalam perjanjian keagenan, prinsipal memberikan kuasa kepada agen untuk menjualkan barangnya dan barang yang dijual kepada pihak ketiga ini nantinya akan langsung dikirim dari prinsipal. Sehingga disini terdapat unsur perwakilan.

Mengenai hubungan antara agen dengan pengusaha ini ada beberapa pendapat diantaranya :

\footnotetext{
${ }^{16}$ Wirjono Prodjodikoro, Loc.cit.

${ }^{17}$ Subekti I, Op.cit., hlm.162
} 
a. Molengraaff, yang mengatakan bahwa hubungan itu bersifat pelayanan berkala.

b. Polak, tidak menyatakan dengan tegas sifat hukum hubungan antara agen perusahaan dengan pengusaha. Beliau menunjuk adanya putusan hakim yang senada dengan pendapat Molengraaff, ada juga yang mengatakan hubungan itu semacam dengan perburuhan.

c. H.M.N. Purwosutjipto, mengatakan hubungan agen dengan pengusaha tidak bersifat pelayanan berkala, dan juga tidak bersifat perburuhan, sebab hubungan tetap bukanlah sifat dari pelayanan berkala dan hubungan yang sama tinggi sama rendah tidak bertentangan dengan sifat pemberian kuasa. $^{18}$

Menurut Munir Fuadi, hubungan antara agen dengan prinsipal (pengusaha), dapat diruaikan sebagai berikut:

1) agen bertindak atas nama prinsipal. Seorang agen akan menjual barang atau jasa untuk dan atas nama pihak prinsipalnya.

2) Pendapatan seorang agen adalah berupa komisi dari hasil penjualan barang/jasa kepada konsumen.

3) Dalam hal keagenan, barang dikirim langsung dari prinsipal kepada konsumen. Sehingga prinsipal mengetahui konsumennya.

4) Pihak prinsipal akan langsung menerima pembayaran harga dari pihak konsumen tanpa melalui agen. ${ }^{19}$

Seperti telah diuraikan diatas, bahwa perjanjian keagenan merupakan perjanjian yang hingga saat ini belum ada aturan yang khusus mengaturnya. Sehingga untuk mengetahui karakteristik perjanjian ini, akan dilihat dari perjanjian yang terdapat di dalam KUHPerdata. Di dalam perjanjian keagenan, terkandung karekteristik perjanjian pemberian kuasa. Bahkan ada yang berpendapat selain mengandung karakteristik perjanjian pemberian kuasa, juga terkandung perjanjian

\footnotetext{
${ }^{18}$ H.M.N.Purwosutjipto, op.cit, hlm. 48

19 Munir Fuady, Pengantar Hukum Bisnis; Menata Bisnis Modern di era Global, Citra Aditya Bakti, Jakarta, 2002, hlm. 244-245
} 
jual beli. Sehingga perjanjian keagenan termasuk dalalm kategori perjanjian campuran. ${ }^{20}$

Untuk mengetahui hukum apa yang berlaku dalam perjanjian campuran dikenal dengan tiga teori, yaitu teori akumulasi, teori absorbsi dan teori sui generis. ${ }^{21}$ Teori ini akan digunakan saat terjadi sengketa antara prinsipal dan agen apabila tidak terdapat dalam perjanjian keagenan yang telah dibuat kedua belah pihak.

(a) Teori Akumulasi

Menurut teori ini, unsur-unsur perjanjian campuran dipilah-pilah lebih dahulu. Kemudian untuk setiap unsur diberlakukan ketentuan-ketentuan perjanjian khusus dalam KUHPerdata yang sesuai. Misalnya untuk unsur jual beli diberlakukan peraturan tentang jual beli dan untuk pemberian kuasa diberlakukan peraturan tentang pemberian kuasa.

(b) Teori Absorbsi

Menurut teori ini hukum yang berlaku bagi perjanjian campuran adalah hukum dari unsur perjanjian yang dominan. Jadi jika dalam perjanjian keagenan unsur pemberian kuasa yang lebih dominan dari unsur perjanjian jual-beli, maka berlakulah ketentuan tentang pemberian kuasa di dalam KUHPerdata.

(c) Teori Sui Generis

Menurut teori ini perjanjian campuran dianggap sebagai perjanjian dengan ciri tersendiri. Ketentuan perjanjian khusus dalam KUHPerdata diperlakukan secara analogis. ${ }^{22}$

Di dalam KUHPerdata, kewajiban dari penerima kuasa diatur dalam Pasal 1800 - 1806 KUHPer. Kewjiban ini akan diuraikan sebagai beriktu:

a. Penerima kuasa diwajibkan selama ia belum dibebaskan, melaksanakan kuasanya, dan ia menanggung segala biaya, kerugian dan bunga yang sekiranya dapat timbul karena tidak dilaksanakannya kuasa tersebut. Begitu pula ia diwajibkan menyelesaikan urusan yang sudah mulai dikerjakannya

\footnotetext{
${ }^{20}$ Suharnoko, op.cit., hlm.45

21 ibid

${ }^{22}$ Ibid
} 
pada waktu si pemberi kuasa meninggal, jika dengan tidak segera menyelesaikannya dapat timbul suatu kerugian (Pasal 1800 KUHPer).

Tugas yang telah disanggupi harus dilaksanakan dengan sebaik-baiknya dan dalam waktu yang disepakati, jika tidak maka si penerima kuasa dapat dituntut mengganti kerugian yang ditimbulkan karena kelalaiannya. Dengan demikian, meskipun meninggalnya si pemberi kuasa, pemberian kuasa berakhir, tetapi si penerima kuasa harus bekerja terus untuk menyelesaikan urusannya dahulu, barulah ia dibebaskan, setelah melaporkan hasilnya kepada para ahli waris dan pertanggung jawab itu diterima baik oleh mereka. Hal ini juga terkandung dalam perjanjian keagenan, bahwa agen harus melaksanakan semua yang tertera di dalam perjanjian keagenan sebagaimana disepakati, dan dapat dikenakan sanksi berupa pemutusan hubungan mitra apabila dalam jangka waktu tertentu tidak berhasil menjualkan produk prinsipal. Perjanjian keagenan tetap berlaku selama jangka waktu yang ditentukan dalam perjanjian.

b. Penerima kuasa tidak saja bertanggung jawab tentang perbuatan-perbuatan yang dilakukan dengan sengaja, tetapi juga tentang kelalaian yang dilakukan dalam menjalankan kuasanya. Namun itu tanggung jawab tentang kelalaian bagi seorang yang dengan cuma-cuma menerima kuasa adalah tidak sebegitu berat seperti yang dapat dimintakan dari seorang yang untuk itu menerima upah (Pasal 1801 KUHPer). Dalam perjanjian keagenan, perjanjian pemberian kuasanya dalah perjanjian kuasa dengan upah. Dimana di dalam perjanjian keagenan jelas tertera jumlah komisi yang diterima agen saat berhasil melakukan transaksi jual beli barang milik prinsipal dengan pihak ketiga.

c. Dalam Pasal 1802 KUHPer ditentukan bahwa si penerima kuasa diwajibkan untuk melaporkan kepada si pemberi kuasa segala sesuatu yang dilakukan olehnya berhubungan dengan tugasnya selaku kuasa. Dalam perjanjian keagenan, kewajiban ini juga ada. Agen harus memberikan laporan hasil penjualan dan pertanggung jawaban barang prinsipal yang ada pada dirinya, 
atau melaporkan jumlah yang telah berhasil dijualkannya kepada pihak ketiga.

Setelah diuraikan mengenai kewajiban penerima kuasa, selanjutnya akan diuraikan mengenai kewajiban Pemberi Kuasa, yang diatur dalam Pasal 1807 - 1812 KUHPer.

a. Dalam Pasal 1808 si pemberi kuasa harus mengganti kepada si penerima kuasa semua pembayaran di muka dan biaya-biaya yang dikeluarkan oleh si penerima kuasa dalam melakukan tugasnya, juga upahnya yang telah diperjanjikan. Kewajiban si pemberi kuasa tetap ada, meskipun usaha si penerima kuasa untuk mencapai tujuan yang dimaksudkan dengan tugasnya, adalah tidak berhasil (gagal) dan kegagalan itu bukan disebabkan oleh kelalaian si penerima kuasa. Hal ini dalam perjanjian keagenan juga dijelaskan secara tegas. Ada biaya iklan, pemberian pelatihan dan ditanggung oleh prinsipal atau sesuai dengan kesepakatan, apakah ditanggung bersama dengan agen. Mengenai besaran komisi juga ditentukan secara tegas dalam perjanjian.

b. Berakhirnya Pemberian Kuasa diatur di dalam Pasal 1813 KUHPer ditentukan mengenai cara berakhirnya pemberian kuasa, yaitu:

1) oleh karena dicabut oleh si pemberi kuasa;

2) oleh karena si penerima kuasa menghendakinya;

3) oleh karena salah satu dari kedua belah pihak meninggal dunia, atau dinyatakan di bawah pengampuan (curatele), atau dinyatakan pailit;

4) oleh karena perempuan, yang menjadi salah satu pihak, kawin.

Selain itu ada juga cara-cara lain yang menyebabkan berakhirnya pemberian kuasa, yaitu kalau pemberian kuasa diadakan untuk tenggang waktu tertentu, dalam hal mana pemberian kuasa terhenti pada akhir tenggang itu, juga berakhir kalau dipenuhinya suatu syarat untuk itu (ontbindende voorwaarde).

c. Pencabutan pemberian kuasa dapat dilakukan sewaktu-waktu dan si pemberi kuasa dapat menuntut supaya surat kuasa diserahkan kembali kepadanya, yaitu untuk menghindari kemungkinan, si penerima kuasa yang tidak jujur, melanjutkan perbuatan-perbuatan selaku penerima kuasa (Pasal 1814 
KUHPer). Pencabutan ini harus diberitahukan kepada pihak ketiga yang berkaitan dengan pemberian kuasa itu. Pencabutan pemberian kuasa juga dapat dilakukan secara diam-diam (stilzwijgend). Pasal 1816 KUHPer menyebutkan suatu contoh, yaitu apabila si pemberi kuasa menunjuk orang lain selaku kuasanya. Dengan ini pemberian kuasa yang pertama harus dianggap dicabut.

d. Penghentian pemberian kuasa yang dilakukan oleh si penerima kuasa tidak boleh dilakukan pada waktu yang tidak layak, dengan akibat si pemberi kuasa akan menderita kerugian (Pasal 1817 KUHPer). Dalam hal ini si penerima kuasa harus mengganti kerugiannya itu, kecuali jika si penerima kuasa itu sendiri akan menderita kerugian agak besar (aanmerkelijke schade) apabila ia meneruskan tugasnya selaku penerima kuasa.

Mengenai agen ini, karakteristiknya juga hampir sama dengan dua pranata yang ada di dalam KUHD yang fungsinya sebagai perantara, yaitu komisioner dan makelar. Komisioner merupakan perantara produsen dalam memasarkan atau menjualkan produknya kepada konsumen yang diatur di dalam KUHD. Mengenai komisioner diatur dalam Bab V, bagian I, pasal 76 sampai dengan 85a, Buku I KUHD. Komisioner adalah orang yang menjalankan perusahaan dengan membuat perjanjian-perjanjian atas namanya sendiri, mendapat provisi atas perintah dan atas pembiayaan orang lain (Pasal 76 KUHD).

Sedangkan makelar adalah seorang perantara yang menghubungkan pengusaha dengan pihak ketiga untuk mengadakan pelbagai perjanjian. ${ }^{23}$ Sebagai perantara atau pembantu pengusaha, makelar mempunyai hubungan yang tidak tetap. Sifat hubungan hukumnya pelayanan berkala dan pemberian kuasa. Dalam melakukan hubungan hukum dengan pihak ketiga, makelar bertindak atas nama pemberi kuasanya. ${ }^{24}$ Berbeda dengan komisioner yang bertindak atas namanya sendiri.

${ }^{23}$ H.M.N. Purwosutjipto, op.cit., hlm.50

${ }^{24}$ Ibid, hlm. 50-51 


\section{KESIMPULAN}

Sehingga dari uraian di atas, maka dapatlah ditarik suatu kesimpulan bahwa :

1. Perjanjian keagenan sama halnya dengan perjanjian komisi merupakan perjanjian pemberian kuasa khusus. Ada beberapa persamaan perjanjian keagenan dengan perjanjian komisi, yaitu merupakan perjanjian pemberian kuasa khusus dengan pemberian upah, bertindak atas nama sendiri, memiliki hak privilege.

2. Oleh karena merupakan perjanjian pemberian khusus, maka perjanjian keagenan tunduk pada aturan dalam KUHPer Buku III, Bab XVI, Bagian II dan III dan dalam KUHD, Buku I, Bab V, Bagian I. Perjanjian ini harus dilaksanakan dengan itikat baik.

3. Apabila terjadi sengketa pada perjanjian keagenan, maka penyelesaiannya merujuk pada perjanjian yang dibuat oleh para pihak dalam perjanjian keagenan. Untuk hal-hal yang tidak diatur secara khusus dalam perjanjian tersebut maka akan diberlakukan ketentuan-ketetuan umum di dalam KUHPerdata.

\section{DAFTAR PUSTAKA}

Abdul Manan, Aspek-Aspek Pengubah Hukum, Kencana, Jakarta, 2006

Abdulkadir Muhammad, Hukum Perjanjian, Penerbit Alumni, Bandung, 1986

H.M.N.Purwosutjipto, Pengertian Pokok Hukum Dagang Indonesai; Pengetahuan Dasar Hukum Dagang, Djambatan, Jakarta, 1999

KRMT. Titodiningrat, Ichtisar Hukum Perdata dan Hukum Dagang, pembangunan, jakarta, 1963

Munir Fuady, Pengantar Hukum Bisnis ; Menata Bisnis Modern di Era Global, Citra Aditya Bakti, Jakarta, 2002

Philip Kotler dkk, Manajemen Pemasaran Perspektif Asia, Penerbit Andi, Yogyakarta, 2000

Sentosa sembiring, Hukum dagang, Citra Aditya Bakti, Bandung, 2008

Solly Lubi, Kita dan Pengembangan Global tahun 2002 , makalah pada seminar nasional Hakim Peradilan Agama, PTA Sumatera Utara Medan, Hotel Darma Deli Medan, 2002

Subekti, Aneka Perjanjian, Citra Aditya Bakti, Bandung, 1995 -, Hukum Perjanjian, Intermasa, Jakarta, 2002

Suharnoko, Hukum Perjanjian ; Teori dan Analisa Kasus, Kencana, Jakarta, 2008

Wirjono Prodjodikoro, Hukum Perdata Tentang Persetujuan-Persetujuan Tertentu, Sumur, Bandung, 1981 